\title{
Angiogenesis, fibrinogenesis and presence of synechiae after exeresis of a swine vocal fold mucosal microflap and use of topical mitomycin- $\mathbf{C}^{1}$
}

\author{
Estudo da angiogênese, fibrogênese e presença de sinéquias após exérese de fragmento de \\ mucosa de pregas vocais de suínos utilizando instrumental frio e mitomicina-C tópica
}

\begin{abstract}
Vinicius Ribas de Carvalho Duarte Fonseca', Osvaldo Malafaia" ${ }^{\mathrm{II}}$, Jurandir Marcondes Ribas Filho" ${ }^{\mathrm{III}}$, Paulo Afonso Nunes Nassif ${ }^{\mathrm{III}}$,

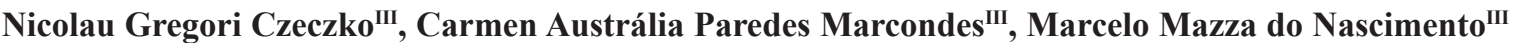

${ }^{I}$ Master in Sciences, Principles of Surgery Post-Graduation Program, University Evangelic Hospital/Evangelic Faculty of Parana, Curitiba-PR, Brazil.

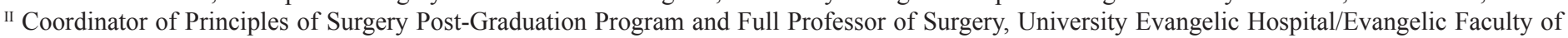
Parana, Curitiba-PR, Brazil.

III $\mathrm{PhD}$, Associate Professor, University Evangelic Hospital/Evangelic Faculty of Parana, Curitiba-PR, Brazil.
\end{abstract}

\begin{abstract}
Purpose: To evaluate swine vocal fold healing in a period of 30 days after topical mitomycin-C application. Methods: Twelve swine underwent exeresis of mucosal flaps from the free edge of the anterior third of both vocal folds with a cold instrument (laryngeal scissors). The animals were divided into two groups: EG (Experimental Group), consisting of 6 animals undergoing topical MMC application $(4 \mathrm{mg} / \mathrm{dL})$ on the operated area for 4 minutes; $\mathrm{CG}$ (Control Group), 6 animals undergoing topical saline solution application on the operated area for 4 minutes. After 30 days, the animals were sacrificed and the larynges were collected and examined for the presence of synechiae as well as a histological immunohistochemical assessment of immature and mature collagen deposition, number of blood vessels and myofibroblasts. Results: Mature collagen deposition in the EG was $452.12 \mu \mathrm{m}^{2}$ and $1332.31 \mu \mathrm{m}^{2}$ in the CG; immature collagen deposition was $1511.73 \mu \mathrm{m}^{2}$ in the EG and $1020.61 \mu \mathrm{m}^{2}$ in the CG. The number of myofibroblasts was 1.556 in the EG and 3.583 in the CG. The number of blood vessels was 2.565 in EG and 6.917 in the CG. There were no synechiae in the two studied groups. Conclusions: There was an increase in immature collagen deposition in the experimental group when compared with the control group. There was a decrease in mature collagen deposition in the experimental group when compared with the control group. There was a decrease in the number of myofibroblasts in the experimental group when compared with the control group. A decrease in blood vessels was observed in the experimental group when compared with the control group. There was no synechia formation in either studied group.
\end{abstract}

Key words: Wound Healing. Vocal Cords. Mitomycin. Collagen. Swine.

\section{RESUMO}

Objetivo: Avaliar a cicatrização de pregas vocais de suínos utilizando mitomicina-C tópica, em 30 dias. Métodos: Doze suínos foram submetidos à exérese de mucosa do bordo livre do terço anterior de ambas as pregas vocais com instrumental frio (tesoura curva) e divididos em dois grupos: Grupo E (GE), composto por seis animais com utilização tópica de mitomicina-C(4 mg/dL) na área cruenta por quatro minutos e Grupo Controle (GC), composto por seis animais com utilização tópica de soro fisiológico na área cruenta por quatro minutos. Após 30 dias os animais foram sacrificados e coletadas amostras das pregas vocais para avaliação de sinéquias e análise histológica com quantificação da deposição de colágeno maduro e imaturo, quantificação do número de vasos sanguíneos e miofibroblastos, por método imunoistoquímico. Resultados: A deposição do colágeno maduro no GE foi de $452,12 \mu \mathrm{m}^{2}$ e $1332,31 \mu \mathrm{m}^{2}$ no GC. A do colágeno imaturo foi de $1511,73 \mu \mathrm{m}^{2}$ no GE e de $1020,61 \mu \mathrm{m}^{2}$ no GC. O número de miofibroblastos foi de 1,556 no GE e de 3,583 no GC. O número de vasos sanguíneos foi de 2,565 no GE e de 6,917 no GC. Não houve formação de sinéquias nos grupo s estudados. Conclusões: No grupo experimento, quando comparado ao controle, houve significativamente aumento da deposição do colágeno imaturo e diminuição da deposição do colágeno maduro, do número de miofibroblastos e de vasos sanguíneos. Não houve formação de sinéquias em ambos os grupos.

Descritores: Cicatrização de Feridas. Pregas Vocais. Mitomicina. Colágeno. Suínos.

${ }^{1}$ Research performed at Research Medical Institute, University Evangelic Hospital / Evangelic Paraná Faculty, Curitiba-PR, Brazil. 


\section{Introduction}

With the progress of laryingology over the past decades, most vocal fold disorders have become treatable. Phonomicrosurgery techniques are based on the understanding of vocal fold pathophysiological mechanisms. The objective of those techniques is to minimize the development of scars, adhesions and stiffness of the mucosal lining, thus achieving objective and subjective vocal pattern improvement. However, scarring is a possibility in any surgical incision ${ }^{1}$, and vocal fold scarring is a challenging occurrence ${ }^{2}$. Caused by lesions or inflammation, it damages the lamina propria of the phonatory mucosa, thus altering its biomechanical properties, with an increase in viscoelasticity leading to reduced vocal fold vibration and difficult-to-manage dysphonia ${ }^{3}$.

Recently, a number of researchers have described vocal fold scarring as the result of poor and disorganized wound healing, characterized by increased density and diminished collagen organization. Normal wound healing takes place as a sequence of well-coordinated events leading to the formation of new tissue. Alterations or therapeutic manipulation during these acute stage events can be very relevant in scar formation ${ }^{4}$.

Conventional vocal fold treatments include the injection of autologous or heterologous materials, slicing of the superficial layer of the vocal mucosa and phonotherapy. Recently, mitomycin-C (MMC) has been used to prevent vocal fold scarring in operations that would normally progress to hypertrophic scar formation ${ }^{5}$.

Mitomycin-C is an antineoplastic agent known to inhibit collagen proliferation and tumor growth. Its antifibrotic effect has prompted several clinical and experimental trials with the aim of curbing the development of scars 5 .

A number of studies have been conducted with MMC in the field of otorhinolaryngology with the objective of reducing hypertrophic scar formation in induced laryngeal traumas ${ }^{6}$, tympanic membrane paracentesis ${ }^{7}$, endolymphatic sac decompression ${ }^{8}$, tracheal reconstruction ${ }^{9}$, external or endoscopic dacryocystostomy, primary and revision ${ }^{10}$, exeresis of glottic and subglottic stenoses ${ }^{11}$ and on vocal folds ${ }^{1}$.

The objective of the present study was to evaluate, through immunohistochemistry, the healing process in swine vocal folds in a period of 30 days after the exeresis of a mucosal fragment with cold instruments and the use of topical MMC, assessing the following parameters: deposition of mature and immature collagen; number of myofibroblasts; number of blood vessels; synechia formation.

\section{Methods}

This study was conducted at the Instituto de Pesquisas Médicas - IPEM (Institute forf Medical Research) of the Hospital Universitário Evangélico de Curitiba/Faculdade Evangélica do Paraná, Curitiba, PR, Brazil and at the Experimental Farm of the Universidade Federal do Paraná in Piraquara, PR, Brazil. The guidelines set by the Colégio Brasileiro de Experimentação Animal (Brazilian College of Animal Experimentation) were followed. The research protocol was approved by the Research Ethics Committee of the Sociedade Evangélica Beneficente of Curitiba.
Twelve swine of the Larger White breed (six males and six females) weighing between 8,700 $\mathrm{g}$ and 11,562 $\mathrm{g}$ (mean $=10,131$ g) and aged between 27 and 31 days were used in this study.

All the swine were evaluated clinically by veterinarians and considered to be healthy. The animals were randomized into two groups: the Experimental Group (EG), composed of six animals, underwent exeresis of mucosal tissue from the free edge of the anterior third of both vocal folds with cold instruments (laryngeal scissors) and application of topical mitomycin-C at a concentration of $4 \mathrm{mg} / \mathrm{dL}$ for four minutes. The Control Group (CG), also composed of six animals, underwent exeresis of mucosal tissue from the free edge of the anterior third of both vocal folds with the same instruments, but with the application of saline for four minutes.

The animals were identified by numbers through eartagging and kept in groups of six swine per sty.

All animals were submitted to a 12-hour fast and the supply of water was withdrawn six hours prior to the surgical procedure. All were anesthetized by the same veterinarian and underwent anesthetic induction by midazolam (Dormonid ${ }^{\circledR} 1 \mathrm{mg} / \mathrm{mL}$ ) at the dose of $0.1 \mathrm{mg} / \mathrm{Kg}$, acepromazine $1 \%\left(\right.$ Acepran $\left.^{\circledR} 1 \%\right)$ at the dose of $0.1 \mathrm{mg} / \mathrm{Kg}$, ketamine $\left(\operatorname{Ketalar}^{\circledR} 50 \mathrm{mg} / \mathrm{mL}\right)$ at the dose of $10 \mathrm{mg} / \mathrm{Kg}$ and atropine $0.5 \mathrm{mg} / \mathrm{mL}$ at the dose of $0.06 \mathrm{mg} / \mathrm{kg}$, all by the intramuscular route.

Following preanesthetic medication, venous access was achieved using the superficial veins of the ears, abdomen or limbs through a $22 \mathrm{G}$ needle. Anesthetic induction was achieved with intravenous administration of Propofol ${ }^{\circledR}$ at the dose of $6 \mathrm{mg} / \mathrm{kg}$, and anesthesia was maintained with the same drug at the dose of 0.4 $\mathrm{mg} / \mathrm{kg}$ intravenously. The animals were monitored by EKG through a cardioscope.

Once anesthetized, the animals were placed in supine and covered with sterile drapes. The head of the table was elevated and a pad was placed under the animal's upper dorsal region in order to rise the angle and facilitate larynx alignment. A Storz ${ }^{\circledR}$ infant anterior commissure laryngoscope was used.

The swine vocal folds were viewed through a D. F. Vasconcelos ${ }^{\circledR}$ light microscope with a straight binocular head, a 400-mm lens and a mounted Storz ${ }^{\circledR}$ camera system.

The exeresis of the mucosal fragments of the vocal folds was initiated by grasping the free edge of the anterior third of each vocal fold with a Bouchayer microforceps (Microfrance), after which the exeresis of the free edge fragment was performed with 3 -mm angled scissors. Following the bilateral exeresis in the area of the resected mucosa, a cotton pledget soaked in 4\% MMC solution was placed for four minutes in the EG, and saline for the same period of time for the $\mathrm{CG}$ animals.

Following anesthetic recovery, the swine were returned to their sties, where the provision of water was resumed and feeding was allowed two hours postoperatively. The animals' diet was supplied twice daily, beginning 24 hours postoperatively.

Thirty days after the surgical procedure, the animals went through the same preanesthetic and anesthetic procedures, followed by electrocution and confirmation of death by cardiorespiratory suppression and mydriatic pupils ${ }^{12}$.

Larynges were removed en bloc from the base of the tongue to the fourth tracheal ring, and the vocal folds were submitted to gross examination for synechiae. An anterior 
longitudinal incision was made in the larynx so as to expose the vocal folds (Figure 1) and for the removal of all muscle tissue (Figure 2) with preservation of the mucosal lining. The specimens were pinned to a rectangular piece of cardboard in order to remain outstretched; The identification of the animal and the anterior region of the vocal fold (operated area) were recorded. At this point, the vocal folds were numbered for microscopical examination such that the pathologist was blinded to the group to which the swine belonged. Later, the flaps were fixed in $10 \%$ buffered formalin for 24 hours.

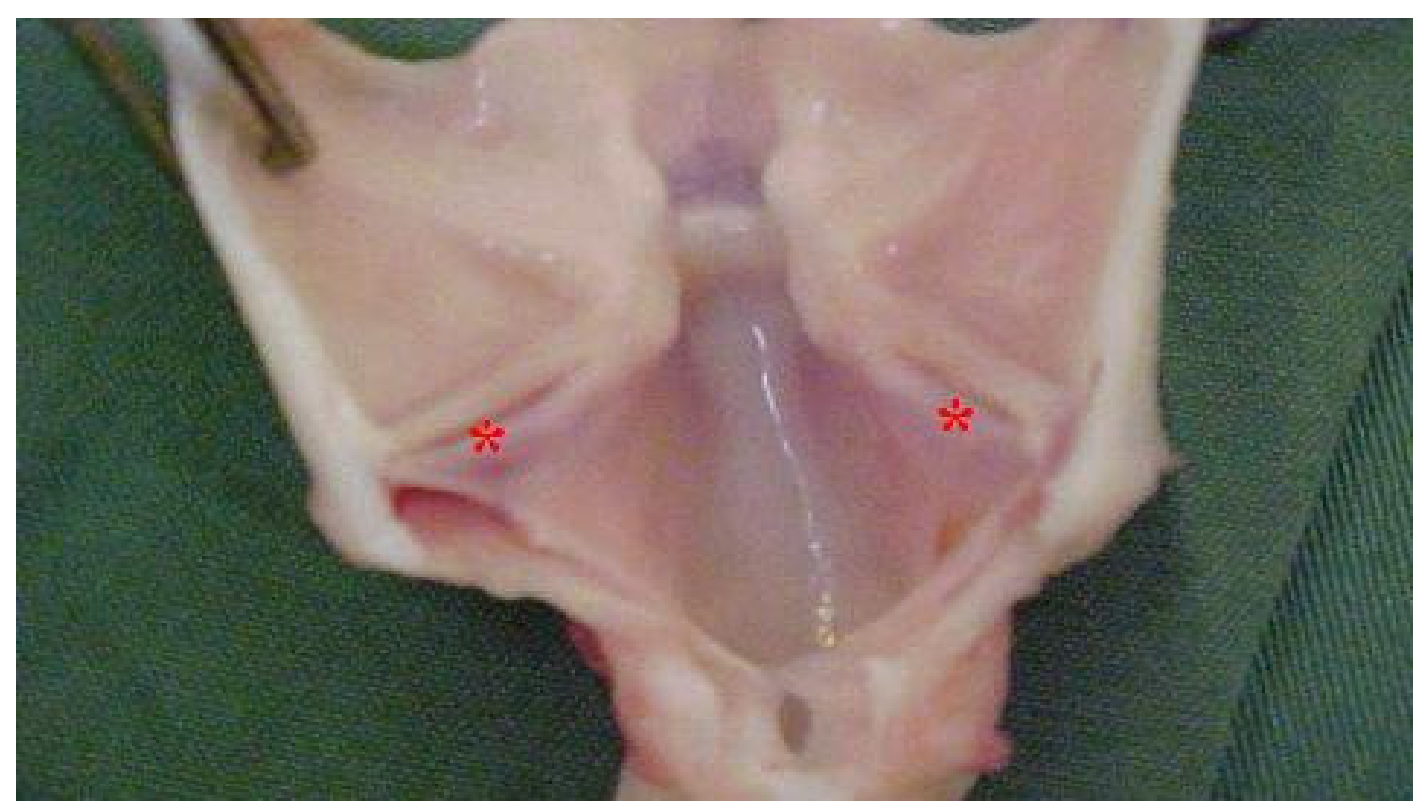

FIGURE 1 - Swine glottis after the opening of the anterior larynx where $(*)$ indicates the area of the exeresis of the mucosal fragment on the anterior third of both vocal folds

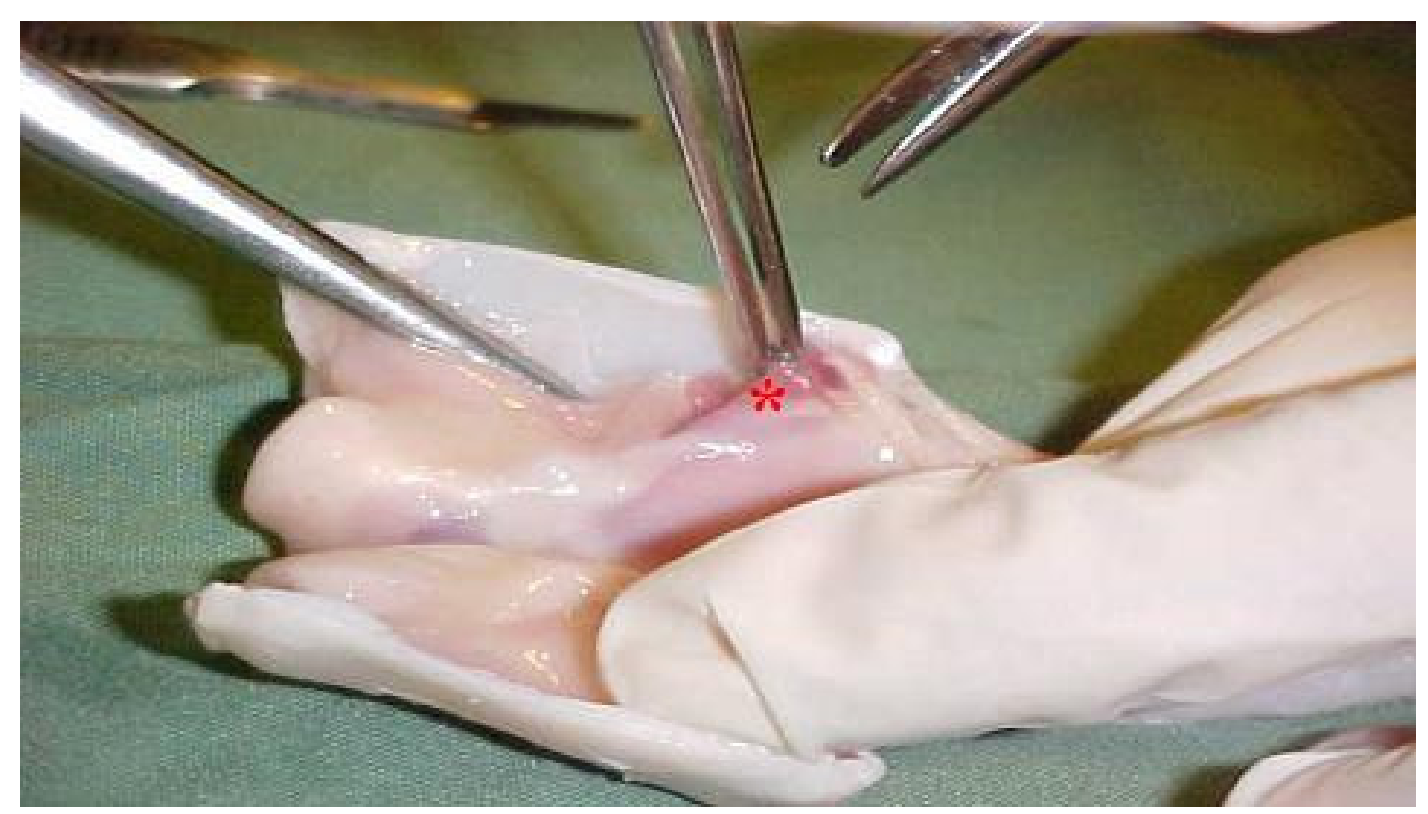

FIGURE 2 - Harvest of vocal fold sample where (*) indicates the area of mucosal fragment exeresis 
For the quantitative assessment of collagen, fragments of the healing area tissue were taken and preserved in separate bottles with $10 \%$ buffered formalin. They were wrapped in porous paper with the mucosal surface turned up, thus keeping the specimen outstretched.

After paraffinization, the surgical specimen blocks from the study animals were cut with a microtome into $4 \mu \mathrm{m}$-thick sections and fixed on silanized slides. Deparaffinization followed. Subsequently, the slides were washed in PBS buffer, $\mathrm{pH} \mathrm{7.2,} \mathrm{and}$ antigen retrieval was accomplished through a $0.2 \%$ hyaluronidase solution in PBS buffer, $\mathrm{pH} 7.2$, in an oven at $37^{\circ} \mathrm{C}$. Following another rinse, nonspecific binding was blocked with a PBS solution plus $5 \%$ albumin for 1 hour in an oven at $37^{\circ} \mathrm{C}$. After two rinses in PBS buffer, the sections were incubated with the primary antibody (polyclonal rabbit antibodies anti-swine type I collagen and anti-bovine type III collagen diluted at 1:500 in PBS/3\% BSA) overnight at $4{ }^{\circ} \mathrm{C}$ in a humidity chamber. After another two rinses with PBS, endogenous peroxidase inactivation was achieved with a methanol solution containing 3\% hydrogen peroxide for 10 minutes. Three 5 -minute rinses were conducted in $0.2 \%$ PBS-Tween washing buffer, $\mathrm{pH}$ 7.2.

The secondary antibody Envision ${ }^{\circledR}$ was added to the sections at room temperature for one hour. After two 5-minute rinses in $0.2 \%$ PBS-Tween buffer, development of color was achieved with diaminobenzidine; the end point of the reaction was checked under light microscopy. New rinse was performed followed by counterstaining with $30 \%$ Harris hematoxylin for 5 minutes. The sections were then dehydrated in xylene and a graded ethanol series and the slides were mounted with Entellan ${ }^{\circledR}$.

For the immunohistochemical study of the number of blood vessels and myofibroblasts, the technique described by Hsu $(1981)^{13}$ was used.

Positive immunohistochemical staining was verified in the areas with brownish pigmentation. Positive and negative controls were used. The slides were coded, with no identification of the animal groups.
For the identification of mature (type I) and immature (type III) collagen, the histological sections were analyzed under an Olympus polarized light microscope at 400X magnification.

The detection of myofibroblasts was performed by counting the positively-stained cells by immunohistochemistry using monoclonal anti-smooth muscle actin antibodies in a highpower field (40X objective), in three different random fields in the area of the healing process, which corresponds to an area of 17.7726 $\mu \mathrm{m}^{2}$, expressed as arithmetic means.

The detection of blood vessels was achieved by counting the number of circular structures positively stained by the antifactor VIII polyclonal antibody, revealing the endothelial cells of the intima of the vessels. The count was performed in the healing area at 40X magnification, in three different random fields.

For the statistical analysis of comparisons between different groups, Friedmann's nonparametric test was applied. For all comparisons, the null hypothesis referred to equal results between groups and the alternative hypothesis, to different results. A value of $P<0.05$ was considered statistically significant.

\section{Results}

No synechiae were found in the study groups.

$$
\text { Evaluation of mature (type I) and immature (type III) }
$$
collagen

There was a statistically significant difference regarding mature collagen quantification when the EG (with MMC) and $\mathrm{CG}(P=0.0022)$ were compared, as well as a decrease in mature collagen in the EG. A statistically significant difference was also found regarding immature collagen quantification when $E G$ and CG were compared $(P=0.0022)$ (Tables 1 and 2).

TABLE 1 - Quantification of mature and imature collagen in the control and experimental groups

\begin{tabular}{ccc}
\hline VARIABLE & CONTROL & EXPERIMENTAL \\
\hline Mature collagen & $1332.31 \pm 77.60$ & $452.12 \pm 76.06$ \\
Immature collagen & $1020.61 \pm 111.81$ & $1511.73 \pm 61.60$ \\
\hline
\end{tabular}

TABLE 2 - Significance between groups

\begin{tabular}{ccc}
\hline VARIABLE & GROUPS & P \\
\hline Mature collagen & Control vs. Experimental & 0.0022 \\
Immature collagen & Control vs. Experimental & 0.0022 \\
\hline
\end{tabular}


Evaluation between groups regarding the number of myofibroblasts and blood vessels

As shown in Table 3, a statistically significant difference was found for the number of myofibroblasts between the groups
( $P=0.014)$, with fewer myofibroblasts in the EG. A statistically significant difference was also noted with regard to the number of blood vessels between the CG and EG $(P=0.006)$, with fewer vessels in the EG.

TABLE 3 - Number de myofibroblasts and blood vessels in the control and experimental groups

\begin{tabular}{cccc}
\hline VARIABLE & CONTROL & EXPERIMENTAL & P* \\
\hline Number of myofibroblasts & $3.583 \pm 0.585$ & $1.556 \pm 0.559$ & 0.014 \\
Number of vessels & $6.917 \pm 0.585$ & $2.565 \pm 0.894$ & 0.006 \\
\hline
\end{tabular}

(*) Significance in Friedmann's nonparametric test, $P<0.05$

\section{Discussion}

In line with studies by other authors ${ }^{1}$ a decrease was observed in total collagen deposition on the vocal folds in the EG. There was a reduction in type I collagen (mature) and an increase in type III collagen (immature), thus denoting a delay in the scarring process and reduced fibroplasia

Garret et al. ${ }^{1}$, demonstrated a decrease in collagen deposition on the submucosa of vocal folds that underwent a microflap procedure and topical MMC application. However, in that study, the deposition of mature and immature collagen was not compared in the EG, which could demonstrate an induction of hypertrophic scarring.

In the present study, there was an increase in immature collagen and a decrease in mature collagen in the topical MMC group, which denotes a delay in maturity and slower remodeling, which could promote more organized healing of the superficial layers of the vocal folds over the long term.

According to Chamson et al. ${ }^{14}$, myofibroblasts are cells that produce predominantly type I collagen, and a reduction in their number could be related to a decreased synthesis of its protein. Only one study evaluated the deposition of myofibroblasts in the assessment of the scarring process of vocal folds. The number of myofibroblasts was noted as a control and assessment factor of healing in swine vocal folds, equally submitted to the exeresis of a mucosal fragment with cold instruments, yet compared with $\mathrm{CO}_{2}$ laser.

In the present study, there was a decrease in the number of myofibroblasts in the EG when compared with the CG, showing the action of MMC on those cells through the induction of apoptosis and reduction of fibroblast proliferation ${ }^{10}$. This fact led to a decrease in mature collagen deposition and an increase in immature collagen, which resulted in reduced fibroplasia.
It is known that angiogenesis is the formation of new blood vessels through a process in which capillary buds develop in response to external chemical stimuli. This occurs during embryogenesis, in the growth of solid tumors and in wound healing. Neovessel development is essential in healing, and is associated with local factors, chemical mediators, extracellular matrix and metabolic gradients. For these reasons, this variable was included in the present study ${ }^{15,16}$.

The present study showed a statistical difference with regard to the number of blood vessels between groups, revealing a decrease in the EG, which denotes a decline in the inflammatory wound healing process through neovascularization, a fact that had never been observed before in experimental studies with the use of topical MMC on vocal folds. Such reduction could have originated in the action of MMC on the extracellular constituents that induce neovascularization, which could also be associated with less collagen deposition due to a decrease in the migration of fibroblasts and components of the inflammatory process.

Further studies with larger samples, longer follow-up and additional variables will be needed to verify those results and to establish the actual factors that reduce the deposition of mature collagen and how vocal cord fibroplasia could be prevented or delayed.

\section{Conclusions}

There was a significant increase in immature collagen deposition, a decrease in mature collagen deposition, a decrease in the number of myofibroblasts, and a decrease in the number of blood vessels in the experimental group when compared with the control group. No synechia formation was observed in either group. 


\section{References}

1. Garrett CG, Soto J, Billante CR, Riddick J, Reinisch L. Effect of mitomycin-C on vocal fold healing in canine model. Ann Otol Rhinol Laryngol. 2001;110:25-30.

2. Krespi YP, Meltzer CJ. Laser surgery for vocal cord carcinoma involving the anterior commissure. Ann Otol Rhinol Laryngol. 1989;98:105-9.

3. Roh JL, Yoon YH. Prevention of anterior glottic stenosis after transoral microresection of glottic lesions involving the anterior commissure with mitomycin C. Laryngoscope. 2005;115:1055-9.

4. Branski RC, Verdolini K, Rosen CA, Hebda PA. Acute vocal fold wound healing in a rabbit model. Ann Otol Rhinol Laryngol. 2005;114:19-24.

5. Roh JL, Yoon YH. Prevention of anterior glottic stenosis after bilateral vocal fold stripping with mitomycin-C. Arch Otolaryngol Head Neck Surg. 2005b;131:690-5.

6. Ingrams DR, Ashton P, Dhingra J, Shah R, Shapshay SM. Slow-release 5 - Fluorouracil and triamcinolone reduces subglotic stenosis in a rabbit model. Ann Otol Rhinol Laryngol. 2000;109:422-4.

7. Jassir D, Buchman SA, Gomes-Marin O. Safety and efficacy of topical Mitomycin-C in miringotomy patency. Otolaryngol Head Neck Surg. 2001;124:368-73.

8. Yazawa Y, Suzuki M, Kitano H, Kitagima K. Intraoperative mitomycin $\mathrm{C}$ in endolymphatic sac surgery for Ménière disease: a pilot study. Orl J Otorhinolaryngol Relat Spec. 1999;61:188-94.
9. Rahbar R, Shapshay SM, Healy GB. Mitomycin-C: effects on laryngeal and tracheal stenosis, benefits and complications. Ann Otol Rhinol Laryngol. 2001;110:1-6.

10. Chung JH, Cosenza MJ, Rahbar R, Metson RB. Mitomycin-C for the prevention of adhesion formation after endoscopic sinus surgery: randomized, controlled study. Otolaringol Head Neck Surg. 2002;126:468-74.

11. Correa AJ, Reinisch L, Sanders DL. Inibition of subglottic stenosis with mitomycin-C in the canine model. Ann Otol Laryngol. 1999;108:1053-60.

12. Close B, Banister K, Baumans V, Bernoth EM, Bromage N. Recommendations for euthanasia of experimental animals. Part 2. DGXT of the European Commission. Lab Anim. 1997;31(1):1-32.

13. Hsu SM, Raine L, Fanger H. Use of avidin-biotin-peroxidase complex $(\mathrm{ABC})$ in immunoperoxidase techniques: a comparison between $\mathrm{ABC}$ and unlabeled antibody (PAP) procedures. J Histochem Cytochem. 1981;29(4):577-80.

14. Chamson A, Garrone R, Avger C, Frey J. Effects of tobacco smoke extraction on the ultrastruture of fibroblasts in culture. J Submicrosc Cytol. 1980;12:401-6.

15. Arnold F, West DC. Angiogenesis in wound healing. Pharmacol Ther. 1991;52:407-22.

16. Pettet GJ, Byrne HM, McElwain DL, Norbury JA. Model of wound healing angiogenesis in soft tissue. Math Biosc 1996;136: 35-63.

\section{Correspondence:}

Vinicius Ribas de Carvalho Duarte Fonseca

Al. Augusto Stellfeld, 1980

80730-150 Curitiba - PR Brazil

Phone: (55 41)3240-5488

ipem@evangelico.org.br

Conflict of interest: none

Financial source: none

Received: August 17, 2009

Review: October 19, 2009

Accepted: November 13, 2009

\section{How to cite this article}

Fonseca VRCD, Malafaia O, Nassif PAN, Czeczko NG, Marcondes CAP, Nascimento MM. Angiogenesis, fibrinogenesis and presence of synechiae after exeresis of a swine vocal fold mucosal microflap and use of topical mitomycin-C. Acta Cir Bras. [serial on the Internet] 2010 Jan-Feb;25(1). Available from URL: http://www.scielo.br/acb 